\title{
The Effects of Prescribed Burning on Silver Sagebrush
}

\author{
RICHARD S. WHITE AND PAT O. CURRIE
}

\section{Abstract}

Prescribed burning was conducted in the spring and fall on mixed grass prairie vegetation to evaluate the effects of fire on silver sagebrush. Climatic conditions and fuel loads at the time of burning were similar in both seasons. Spring burning under good soil moisture conditions resulted in low mortality of sagebrush and vigorous sprouting. Fall burning under dry conditions resulted in greater mortality and reduced shrub regrowth. Fire intensity in both spring and fall was directly related to mortality and inversely related to subsequent growth. As intensity increased, mortality became greater and regrowth became less. This range in response to fire indicates that burning can be used advantageously to manage plant communities containing silver sagebrush.

Burning has long been recognized as an effective method of controlling big sagebrush (Artemisia tridentata). Pechanec et al. (1954) reported good control and increased forage production when burning was conducted in late summer, and Cook (1958) showed that burning could reduce big sagebrush cover by as much as $95 \%$ under uniform burning conditions. Burning has also given good control of three-tip sagebrush (Artemisia tripartita), and it can readily kill black sagebrush (Artemisia nova) and low sagebrush (Artemisia arbuscula) when sufficient fuel is available to carry a fire (Wright et al. 1979). The effects of fire on silver sagebrush (Artemisia cana) have been less thoroughly documented. Vallentine (1971) stated that kill on silver sagebrush is low because of post-burning resprouting, and Wright et al. (1979) classified this species as being slightly harmed by burning. These conclusions, however, were primarily based upon incidental observations from studies that dealt with more general effects of burning. Studies dealing directly with burning of silver sagebrush have been lacking.

Silver sagebrush is geographically widespread. It is found from British Columbia to Saskatchewan and south to California, Utah and New Mexico (Cronquist 1955). In the Northern Great Plains, silver sagebrush is usually found on more mesic sites than big sagebrush, and it most often occupies productive, fertile soils that are relatively deep (Thatcher 1959). In many situations, silver sagebrush density can become high enough to reduce production of associated grasses and forbs. When this happens, brush control is desirable. Beetle (1960) estimated that silver sagebrush occupies more than 13 million ha in the 11 western states. As such, silver sagebrush ranks second in importance to big sagebrush. Although it merits serious consideration in many parts of its range, silver sagebrush has received little research emphasis with respect to optimum management for cover or forage. Some subspecies or ecotypes apparently provide palatable browse (Johnson and Nichols 1970), while others are almost useless as sources of forage. Additional information is therefore needed to achieve more efficient management on rangelands with silver sagebrush.

The purpose of our research was to obtain baseline information on management of silver sagebrush communities. Specifically our objectives were to examine fire as a management tool and to measure silver sagebrush response under variable burning conditions.

\footnotetext{
Authors are research plant physiologist and range scientist, respectively, USDA ARS, Livestock and Range Research Station, Miles City, Mont. 5930I.

This research is a contribution from the Western Region, USDA, ARS Livestock and Range Research Station and the Montana Agricultural Experiment Station, Journal Series No. 1150.
}

\section{Methods}

Prescribed burning was conducted at 2 study sites on the Livestock and Range Research Station near Miles City, Mont. Vegetation was typical of mixed grass prairies throughout the Northern Great Plains with western wheatgrass (Agropyron smithii) and blue grama (Bouteloua gracilis) being the major grass species. Other species included threadleaf sedge (Carex filifolia), needleand-thread (Stipa comata), green needlegrass (Stipa viridula), and annual brome grasses (Bromusspp.). Silver sagebrush was abundant.

Prescribed burning was completed on about 20 ha in either mid-April of 1977 or early October of 1979. These periods provided soil moisture conditions that corresponded to the extremes that might be anticipated in prescribed burning. The spring burn was carried out shortly after spring runoff when the soil moisture content was near field capacity. The fall burn was conducted after summer drought had substantially reduced soil moisture throughout the soil profile. At this time plants were under proportionately greater water stress than those burned in spring. The spring burn was a headfire and the fall burn was a backfire. Fuel amounts were comparable on both areas and ranged from $300 \mathrm{~kg} / \mathrm{ha}$ in blue grama vegetation to more than $1,000 \mathrm{~kg} / \mathrm{ha}$ in western wheatgrass. Climatic conditions at the time of burning were similar. Burning was conducted when ambient temperature was about $21^{\circ} \mathrm{C}$ and wind speed less than $8 \mathrm{~km} / \mathrm{hr}$.

Measurements of the response of sagebrush to fire were made during the first July following burning. This sampling date permitted any degree of plant recovery from burning, and it allowed sprouting to progress through an initial spring-summer growth period. Measurements were taken on 210 individual silver sagebrush plants at regular intervals along 10 line transects through the burned areas. Plants were classified in one of 3 progressively higher fire-intensity groups: foliage consumed, foliage and twigs consumed with main stems remaining, and entire plant burned to the stump. Observations on each plant included survival, number of sprouts, height of sprouts at plant center, and an index of canopy cover. The canopy cover index was determined by regarding the sprouts as growing in an elliptical shape. The linear intercept of foliage was measured along the major and minor axes and the canopy cover index was calculated by adding both values. Mortality was evaluated using Chi-square analysis by regarding fire-intensity groups as distinct classes. Growth responses were evaluated with fire-intensity classes considered as separate treatments and pre-burn plant size as a covariant. Individual plants constituted independent observations in a completely randomized design, and standard statistical techniques were used to interpret results.

\section{Results and Discussion}

Spring and fall burning both resulted in complete topkill of silver sagebrush regardless of fire intensity. Plants that had only the foliage consumed however, tended to resprout sooner than those that were completely burned. Examination of resprouts revealed no distinct difference in point of origin among fireintensity classes. An increase in burning intensity therefore acted to retard resprouting rather than physically change the location of 


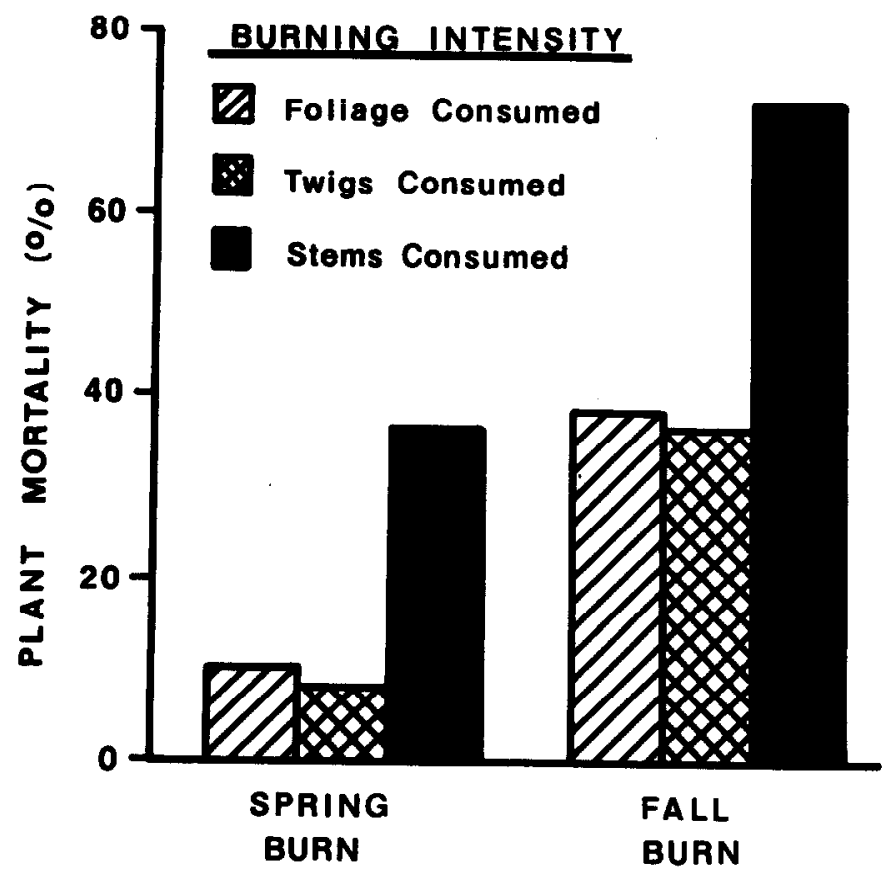

Fig. 1. Mortality of silver sagebrush expressed as a function of burning intensity and time of burning.

resprouting. Pre-burn plant size apparently had little effect on subsequent survival or growth. Covariance analysis showed that coefficients for size were not significant in either spring or fall burning.

Silver sagebrush survival depended upon fire intensity and the time of year when burning was undertaken (Fig. 1). In the spring, soil moisture was high, and sagebrush plants were just becoming physiologically active after winter dormancy. At this time about one-third of the plants that were burned to the stump were killed by fire. Plants that were less thoroughly burned, however, sustained mortalities of less than $10 \%$. Considerably higher plant mortality was achieved by burning under dry fall conditions after sagebrush plants had completed growth and reproductive activity. After fall burning about three-fourths of the plants that were burned to the stump died, and almost $40 \%$ of the rest were killed by fire. Mortality differences between burning periods were highly significant $(R<0.01)$. This demonstrated that good silver sagebrush control with at least $35 \%$ kill could be achieved by burning under dry conditions in the fall. Better control can probably also be obtained by proper fuel management. Because there was a two-to three-fold increase in kill when plants were completely burned, it is more

Table 1. Mean growth of silver sagebrush in relation to fire intensity. Measurements were made in July of 1977 or 1980 after plants passed through one spring growing period.

\begin{tabular}{lccc}
\hline \hline & \multicolumn{3}{c}{ Growth characteristics } \\
\cline { 2 - 4 } Fire intensity & $\begin{array}{c}\text { Number of } \\
\text { resprouts }\end{array}$ & $\begin{array}{c}\text { Center } \\
\text { height }(\mathrm{mm})\end{array}$ & $\begin{array}{c}\text { Canopy } \\
\text { index (mm) }\end{array}$ \\
\hline & \multicolumn{3}{c}{ Spring burn } \\
\cline { 2 - 4 } Foliage consumed & $4.5 \mathrm{a}^{1}$ & $322 \mathrm{a}$ & $394 \mathrm{a}$ \\
Twigs and foliage consumed & $3.8 \mathrm{a}$ & $305 \mathrm{a}$ & $424 \mathrm{a}$ \\
Completely burned & $3.3 \mathrm{~b}$ & $216 \mathrm{~b}$ & $358 \mathrm{a}$ \\
& \multicolumn{4}{c}{ Fall burn } \\
Foliage consumed & $10.3 \mathrm{a}$ & $188 \mathrm{a}$ & $341 \mathrm{a}$ \\
Twigs and foliage consumed & $13.3 \mathrm{a}$ & $188 \mathrm{a}$ & $279 \mathrm{a}$ \\
Completely burned & $4.2 \mathrm{~b}$ & $56 \mathrm{~b}$ & $96 \mathrm{~b}$ \\
\hline
\end{tabular}

'Differences between mean values within growth characteristics are significant $(P<0.05)$ when followed by a different letter.

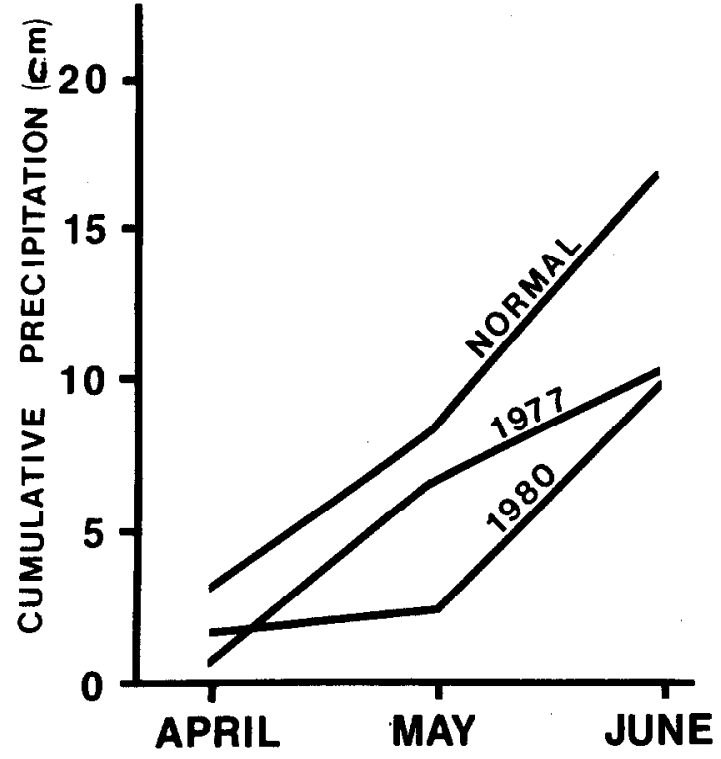

Fig. 2. Precipitation distribution during the first growing season after burning. Rain received in 1977 provided moisture for growth after spring burning, whereas 1980 rainfall contributed to plant growth after fall burning.

advantageous to have a more intense burn. One way of achieving this would be to defer grazing before a planned burn. This would serve to provide more fuel and contribute to a more intense fire.

Precipitation during the first growing season after burning was below normal for both spring-and fall-burned treatments (Fig. 2). This likely resulted in less regrowth than might be observed under normal rainfall. In contrast, differences in survival probably cannot be attributed to precipitation differences between years. April rainfall was similar in each year, and total precipitation during the spring growing period was almost identical by the end of June. Drier conditions in May, 1980, seemed to delay rapid stem elongation in fall-burned plants, but silver sagebrush plants sprouted at about the same time in both years.

As burning intensity increased, regrowth of individual silver sagebrush plants decreased (Table 1). This trend was most apparent on the fall-treated site where drier soil conditions prevailed before burning and during the growing season. It was noticeable to a lesser extent on the spring-treated site where more favorable soil moisture conditions existed before burning and during the growing season. Post-burn growth under the more favorable conditions associated with spring burning was characterized by sagebrush plants with relatively few sprouts. Height growth exceeded $20 \mathrm{~cm}$ for plants that were completely burned, and it surpassed $30 \mathrm{~cm}$ for less seriously injured plants. Sprouts assumed a bushy growth form with dense foliage and canopy indices above $350 \mathrm{~mm}$. Post-burn growth under the more adverse growing conditions associated with fall burning was characterized by proportionately more sprouts, reduced plant height, and lower canopy indices. Plants with twigs and/or foliage consumed sprouted prolifically and usually had more than 10 new shoots per plant. By early July these shoots failed to reach a height of $20 \mathrm{~cm}$. In comparison, plants that were completely burned had about 4 sprouts per plant and regrowth of less than $6 \mathrm{~cm}$.

In general, burning under favorable spring moisture conditions before plants began rapid stem growth resulted in low mortality and vigorous sprouting of silver sagebrush. Consequently, brush cover was soon restored to its original pre-burn condition. Burning under dry fall conditions, in contrast, had a more lasting effect. Mortality was relatively high and canopy cover was substantially reduced. This differential response to burning under two different moisture conditions and phenological stages of development suggests that fire can be advantageously used to alter plant communities containing silver sagebrush. When palatable subspecies or 
ecotypes are present, burning should be conducted in the spring. Favorable moisture conditions will normally result in abundant, tender sprouts that can be utilized for grazing, and stands may be maintained with little loss of silver sagebrush. If unpalatable subspecies or ecotypes are present and brush control is an objective, burning should be carried out in the fall. Shrubs usually will be under more moisture stress with drier soil, and higher mortaility can be expected.

\section{Literature Cited}

Beetle, A.A. 1960. A study of sagebrush-Section Tridentatae of Artemisia. Wyom. Agric. Exp. Sta. Bull. 368.83 p.

Cook, C.W. 1958. Sagebrush eradication and broadcast seeding. Utah Agr. Exp. Sta. Bull. 404.
Cronquist, A. 1955. Vascular plants of the Pacific Northwest. Part 5: Compositae. Univ. Washington Press, Seattle.

Johnson, J.R., and J.R. Nichols. 1970. Plants of South Dakota grasslands. South Dakota Agr. Exp. Sta. Bull. 566.

Pechanec, J.F., G. Stewart, and J.P. Blaisdell. 1954. Sagebrush burninggood and bad. USDA Farm Bull. 1948 (Rev.).

Thatcher, A.P. 1959. Distribution of sagebrush as related to site differences in Albany County. Wyoming. J. Range Manage. 12:55-61.

Vallentine, J.F. 1971. Range development and improvements. Brigham Young University Press, Provo, Utah.

Wright, H.A., L.F. Neuenschwander, and C.M. Britton. 1979. The role and use of fire in sagebrush-grass and pinyon-juniper plant communities. A state-of-the-art review. USDA Forest Serv. Gen. Tech. Rep. INT-58. 